\title{
Persistence of cervical human papillomavirus infection among cohort of women in Awka, Nigeria
}

\author{
${ }^{{ }^{*} 1}$ Ezebialu, C. U., ${ }^{2}$ Ezebialu, I. U., and ${ }^{2}$ Ezenyeaku, C. C. \\ ${ }^{1}$ Department of Applied Microbiology and Brewing, Nnamdi Azikiwe University, Awka, Nigeria \\ 2Department of Obstetrics and Gynaecology, College of Medicine, Chukwuemeka Odumegwu Ojukwu University, \\ Awka, Nigeria \\ *Correspondence to: nenyeume@yahoo.com;08066528090
}

\section{Abstract:}

Background: Many women are known to contract human papilloma virus (HPV) infection in their lifetime but only a few develop cervical cancer. One of the major factors that contribute to development of cervical cancer is HPV persistence. Several other factors including viral load have been implicated in cervical cancer development. This work therefore intends to investigate the persistence of cervical HPV infection among cohort of women in Awka, Nigeria.

Methodology: A cohort of 58 women with normal Papanicolaou (Pap) test but positive HPV DNA selected from a population of 410 women at baseline were followed up over a period of 6 months from April to October 2015. Cervical specimens collected were subjected to HPV DNA test and viral quantification using TaqMan Real Time PCR and cervical cytology. Risk factors were obtained using semi structured interviewer administered questionnaires. Variables were analysed using descriptive statistics and T-test on IBM SPSS statistics version 21.0 and EPI INFO ${ }^{\mathrm{TM}}$ 7.0

Results: At the 6-month follow up, cervical HPV infection persisted in 29 women, representing $50 \%$ of the women followed up. Among the 29 women, 7 (24.1\%) developed abnormal Pap smear (Low grade Squamous Intraepithelial Lesion). Factors significantly associated with persistence at bivariate analysis of HPV include previous sexually transmitted infection (STI) $(p=0.005)$, HIV positivity $(p=0.04)$, HIV positivity but no anti-retroviral drugs $(p=0.014)$, HPV 16 infection $(p<0.0001)$ and age less than 40 years $(p<0.0001)$. At multinomial logistic regression, only age above 17 years at first sexual intercourse $(p=0.003, \mathrm{CI}=0.012-0.392)$ and multiple lifetime sexual partners $(p=0.021, \mathrm{CI}=0.20-0.726)$ were statistically significant.

Conclusion: High risk HPV infection, in addition to other factors peculiar to an individual may influence HPV persistence

Key words: cervical cancer, human papillomavirus, persistence, cytology, risk factors, infection

Copyright 2021 AJCEM Open Access. This article is licensed and distributed under the terms of the Creative Commons Attrition 4.0 International License $<$ a rel="license" href="http://creativecommons.org/licenses/by/4.0/", which permits unrestricted use, distribution and reproduction in any medium, provided credit is given to the original author(s) and the source. Editor-in-Chief: Prof. S. S. Taiwo

\section{Persistance de l'infection cervicale par le papillomavirus humain parmi une cohorte de femmes à Awka, Nigéria}

\author{
${ }^{* 1}$ Ezebialu, C.U., ${ }^{2}$ Ezebialu, I.U., et ${ }^{2}$ Ezenyeaku, C. C. \\ ${ }^{1}$ Département de microbiologie appliquée et brassage, Université Nnamdi Azikiwe, Awka, Nigéria \\ ${ }^{2}$ Département d'obstétrique et de gynécologie, Collège de médecine, Université Chukwuemeka Odumegwu Ojukwu, \\ Awka, Nigéria \\ *Correspondance à: nenyeume@yahoo.com; 08066528090
}




\begin{abstract}
Abstrait:
Contexte: De nombreuses femmes sont connues pour contracter une infection au virus du papillome humain (VPH) au cours de leur vie, mais seules quelques-unes développent un cancer du col de l'utérus. L'un des principaux facteurs qui contribuent au développement du cancer du col de l'utérus est la persistance du VPH. Plusieurs autres facteurs, y compris la charge virale, ont été impliqués dans le développement du cancer du col de l'utérus. Ce travail vise donc à étudier la persistance de l'infection cervicale au VPH parmi la cohorte de femmes à Awka, au Nigeria.
\end{abstract}

Méthodologie: Une cohorte de 58 femmes avec un test de Papanicolaou (Pap) normal mais un ADN HPV positif sélectionné parmi une population de 410 femmes au départ ont été suivis sur une période de 6 mois d'avril à octobre 2015. Les échantillons cervicaux collectés ont été soumis à l'ADN HPV. test et quantification virale à l'aide de la PCR en temps réel TaqMan et de la cytologie cervicale. Les facteurs de risque ont été obtenus à l'aide de questionnaires semi-structurés administrés par les intervieweurs. Les variables ont été analysées à l'aide de statistiques descriptives et d'un test T sur IBM SPSS statistics version 21.0 et EPI INFOTM 7.0

Résultats: Au suivi de 6 mois, I'infection cervicale au VPH persistait chez 29 femmes, soit 50\% des femmes suivies. Parmi les 29 femmes, $7(24,1 \%)$ ont développé un test Pap anormal (lésion squameuse intraépithéliale de bas grade). Les facteurs significativement associés à la persistance lors de l'analyse bivariée du VPH comprennent les antécédents d'infection sexuellement transmissible (IST) $(p=0,005)$, la positivité au VIH $(p=0,04)$, la positivité au VIH mais pas d'antirétroviraux $(p=0,014)$, l'infection au VPH $16(p<0,0001)$ et moins de 40 ans $(p<0,0001)$. Lors de la régression logistique multinomiale, seuls les âges supérieurs à 17 ans lors du premier rapport sexuel $(p=0,003$, IC $=0,012-0,392)$ et les multiples partenaires sexuels à vie $(p=0,021, \mathrm{IC}=0,20-0,726)$ étaient statistiquement significatifs.

Conclusion: Une infection au VPH à haut risque, en plus d'autres facteurs propres à un individu, peut influencer la persistance du VPH

Mots clés: cancer du col de l'utérus, papillomavirus humain, persistance, cytologie, facteurs de risque, infection

\section{Introduction:}

Persistence of human papillomavirus (HPV) infection is a known cause of cervical cancer. About $80 \%$ of women will acquire an HPV infection in their lifetime (1), and up to $50 \%$ of those infections will be with a high-risk type $(1,2,3)$. In majority of the infections, the immune system will suppress the virus and infection is only transient (4) with a clearance rate of about $70 \%$ in one year and about $90 \%$ in two years (5). In some women however, the infection will become persistence because of poor immune response $(6,7)$ and this may progress and lead to the development of cervical cancer (8). Factors that determine the clearance and persistence of HPV DNA in a person include host factors such as tobacco smoking, prolonged use of oral contraceptives, pregnancy, HIV, parity, health status, and viral factors such as oncogenicity of the HPV type involved and viral load.

High viral load has been suggested to influence HPV persistence though interests were mainly on high-risk types such as HPV type 16 and $18(9,10)$. It has been suggested that measurement of viral load could help to identify women who have greater risk of persistent HPV infection and also that women with high viral load but normal cytology could be at risk of HPV persistence $(11,12,13,14)$. This issue of viral load remains controversial and still subject to further verifications

The objectives of this study are to quantify the genome copies in patients with persistent HPV infection in order to determine the threshold copies that may likely trigger the progression to abnormal cervical cytology, and to also determine the factors that influence HPV persistence.

\section{Materials and method:}

\section{Study population}

This included cohort of 58 women with normal Pap test but positive HPV DNA at the baseline study. This cohort is part of 410 women who were assessed in the initial survey result of which has been published elsewhere (15). These women were recalled after six months for follow up. The participants were not on any treatment for the condition during the follow up period

\section{Ethical consideration}

Ethical approval was obtained from the hospital ethics committee. Oral and written consent were obtained from the participants before enrolling them

\section{Collection of data on risk factors for persistence of HPV infection from the study participants} Data collection was carried out using pretested semi structured interviewer administered questionnaires. Detailed socio-demographic information of each patient, including patient's age, and smoking habits, reproductive history, sexual habit of the woman and her partner, previous exposure to STDs, and life 
time use of contraceptive were obtained. The questionnaire was administered to each participant in a private room to ensure confidentiality and this preceded sample collection for each participant. The questionnaires were coded with numbers that corresponded with those on the slides and collection bottles of each participant.

\section{Specimen collection}

The participants were asked to lie on a couch in the dorsal position. The vulva was cleaned with swab soaked with normal saline. Disposable speculum was inserted into the vagina and opened to expose the cervix for specimen collection. To collect specimen for Pap test, an Ayre spatula was inserted into the external cervical os (opening) and rotated through 360 degrees to take the cervical smear. This was immediately smeared on a glass slide and fixed immediately in $95 \%$ alcohol and then transferred to the pathology laboratory for processing.

To collect the specimen for HPV DNA test, a cytobrush was introduced into the external cervical os and rotated through 360 degrees. The cytobrush was then transferred immediately into a collection bottle containing Phosphate Buffered Saline (PBS) and stored at $-20^{\circ} \mathrm{C}$ until it was taken to the laboratory. The collection bottle was swirled to make sure that the PBS was well mixed with the tip of the cytobrush.

\section{Cervical cytology (Papanicolaou test)}

A smear of the cervical exfoliated cells collected using Ayres spatula was made on a grease-free slide, fixed, stained and examined microscopically for the dysplastic cells as characterized by anaplasia, hyperchromatism and large nucleus (16).

\section{Viral DNA isolation}

Viral DNA was extracted from GITC lysates using High Pure Viral DNA kit (Roche, UK). The High Pure Kit uses Spin Column method. The Spin Column method of DNA extraction is based on the principle of selective adsorption of viral DNA onto silica membrane and micro-centrifugation to remove impurities.

\section{HPV type detection and quantification by real- time PCR assay}

HPV genome copies were amplified by TaqMan real time PCR assay using commercially prepared primer/probe mixes from Life River Technology, China. Type specific probe/ primer (synthesized by Invitrogen UK (Life Technology, UK) mixes were used for typing of HPV (Table 1). The primers were designed based on E1, E6-E7 and L1 regions of the HPV genome. The primer sets were GP168 (for HPV types $11,16,18$ and any other type); MY313 (for HPV types 31, 33 and others), OLIS35 (for HPV35 and others), and CpG mix were used for the HPV detection.

The samples numbers including the controls were carefully listed on the worksheet. The 2x universal master mix (Applied Biosystem, UK) containing enzyme and primers were prepared according to Manufacturer's instructions. A $40 \mu \mathrm{l}$ of the master mix was pipetted into the wells on the PCR plates and $10 \mu l$ of the viral DNA samples and standards (Life River Technology, China) were added into appropriate wells to make up $50 \mu \mathrm{l}$ of the reaction volume.

The real time PCR system is OneStep Plus Real Time PCR 96 system (Applied Biosystem, UK). The plates were sealed after all the additions and the thermal profile for real time PCR was set as shown in Table 2. Real time PCR is a software driven analysis therefore, the progress and amplification were monitored on the computer. The standard was used to generate a calibration curve from which all sample viral loads were determined.

\section{Statistical analysis}

Relationship between variables was analysed using descriptive statistics on IBM SPSS version 21.0. EPI INFO ${ }^{\mathrm{TM}} 7.0$ was used to analyse $2 \times 2$ tables. Independent sample T-test was use to compare the mean of the viral loads and $p$ value for significance was set at $<0.05$. 
Table 1: Primer sequences $5^{\prime}$ to $3^{\prime}$ for all the HPV types

\begin{tabular}{|c|c|}
\hline & Primer Sequences $5^{\prime}$ to $3^{\prime}$ \\
\hline $\begin{array}{l}\text { HPV-11F } \\
\text { HPV-11R } \\
\text { HPV-16 F } \\
\text { HPV-16 R } \\
\text { HPV-16 SF } \\
\text { HPV-16 SR } \\
\text { HPV-18 F } \\
\text { HPV-18 R } \\
\text { HPV-31 F } \\
\text { HPV-31 R } \\
\text { HPV- } 33 \text { F } \\
\text { HPV-33 R } \\
\text { HPV-35 F } \\
\text { HPV-35 R } \\
\text { MYO9-F } \\
\text { MY11-R } \\
\text { GP5-F } \\
\text { GP6-R } \\
\text { GP Plus F } \\
\text { GP Plus R } \\
\text { CPF } \\
\text { CPR } \\
\text { OIIF } \\
\text { OIIR } \\
\text { OII PIuS F } \\
\text { OIi Plus R }\end{array}$ & 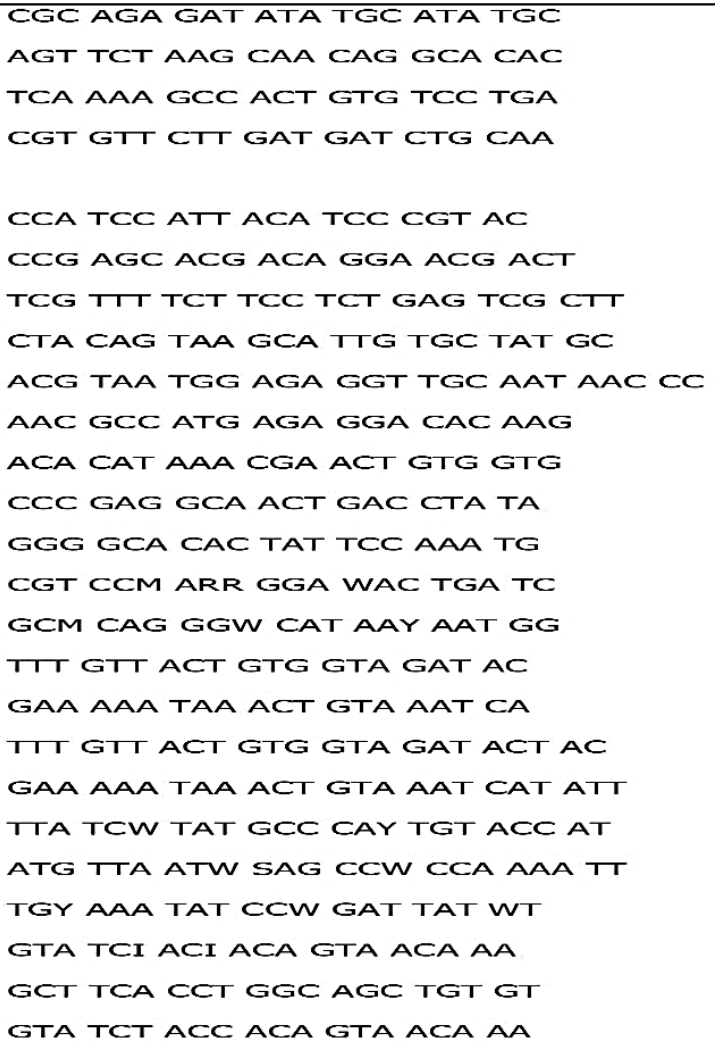 \\
\hline
\end{tabular}

Table 2: Real Time PCR Thermal Profile

\begin{tabular}{cccc}
\hline Step & Temp. & Time & No of cycle \\
\hline UNG enzyme reaction & $50 \mathrm{C}$ & $2 \mathrm{~min}$ & 1 \\
Taq enzyme activation & $95 \mathrm{C}$ & $5 \mathrm{~min}$ & 1 \\
Denature & $94 \mathrm{C}$ & $15 \mathrm{sec}$ & 45 \\
Anneal, extend and data collected & $57 \mathrm{C}$ & $30 \mathrm{sec}$ & 45 \\
\hline
\end{tabular}

\section{Results}

In the baseline study (15), $82(20.0 \%)$ of the 410 participants were HPV positive out of which $75(91.5 \%)$ had normal cervical cytology. These 75 eligible participants were invited for the prospective study but only 58 $(77.3 \%)$ responded and were follow up for a period of 6 months. At the 6-month follow up, cervical HPV infection persisted in 29 participants representing $50 \%$ of the participants. Among these 29 participants, 7 (24.1\%) developed abnormal Pap smear (Low grade Squamous Intraepithelial Lesion).

In the bivariate analysis, factors signi- ficantly associated with HPV persistence after 6 months follow up include; previous STI $(p=$ $0.005)$, HIV positivity $(p=0.04)$, HIV positivity but no anti-retroviral drugs $(p=0.014)$, HPV 16 infection $(p<0.0001)$ and age less than 40 years $(p<0.0001)$ (Table 4$)$. At multinomial logistic regression, only age $>17$ years at first sexual intercourse $(p=0.003, \mathrm{CI}=0.012-0.392)$ and multiple lifetime sexual partners $(p=0.021$, $\mathrm{CI}=0.20-0.726$ ) were statistically significant. The mean viral load was significantly higher among age group $<40$ years $(p=0.029)$, parity group $\leq 4(p=0.015)$, and HPV type $18(p=$ 0.036) (Table 5). 
Table 3: Cervical status of the participants with normal cervix at baseline after 6 months follow up

\begin{tabular}{ccccccc}
\hline HPV result & $\begin{array}{c}\text { Normal } \\
\mathrm{n}(\%)\end{array}$ & $\begin{array}{c}\text { LSIL } \\
\mathrm{n}(\%)\end{array}$ & $\begin{array}{c}\text { HSIL } \\
\mathrm{n}(\%)\end{array}$ & $\begin{array}{c}\text { Cancer } \\
\mathrm{n}(\%)\end{array}$ & $\begin{array}{c}\text { Total } \\
\mathrm{n}(\%)\end{array}$ & $p$ value \\
HPV+ & $22(75.9)$ & $7(24.1)$ & 0 & 0 & $29(50.0)$ & $<0.05$ \\
HPV- & $29(100 \%)$ & $0(0.0 \%)$ & 0 & 0 & $29(50.0)$ \\
\hline Total & $51(87.9)$ & $7(12.1)$ & 0 & 0 & $58(100)$ \\
\hline
\end{tabular}

LSIL= Low grade Intra epithelial Lesion; HSIL = High grade Intra epithelial Lesion

Table 4: Relationship between persistence of cervical HPV infection after 6 months in participants with normal cervix at baseline and some select variables

\begin{tabular}{|c|c|c|c|c|}
\hline Factor & Description & Cleared n (\%) & Persisted n (\%) & $p$ value \\
\hline Previous STI $(n=52)$ & $\begin{array}{l}\text { Yes } \\
\text { No }\end{array}$ & $\begin{array}{c}12(30) \\
11(91.7)\end{array}$ & $\begin{aligned} 28(70.0) \\
1(8.3)\end{aligned}$ & 0.005 \\
\hline Abnormal discharge $(n=45)$ & $\begin{array}{l}\text { Yes } \\
\text { No }\end{array}$ & $\begin{array}{c}1(11.1) \\
23(63.9)\end{array}$ & $\begin{array}{c}8(88.9) \\
13(36.1)\end{array}$ & 0.014 \\
\hline Vaginal rash $(n=55)$ & $\begin{array}{l}\text { Yes } \\
\text { No }\end{array}$ & $\begin{array}{l}4(36.4) \\
22(50.0)\end{array}$ & $\begin{array}{l}7(63.6) \\
22(50.0)\end{array}$ & 0.64 \\
\hline Method of contraception $(n=56)$ & $\begin{array}{l}\text { Hormonal } \\
\text { Others }\end{array}$ & $\begin{array}{c}12(100) \\
15(34.09)\end{array}$ & $29(65.91)$ & 0.0002 \\
\hline HIV status $(n=58)$ & $\begin{array}{l}\text { Positive } \\
\text { Negative }\end{array}$ & $\begin{array}{c}1(14.3) \\
28(56.0)\end{array}$ & $\begin{array}{l}6(85.7) \\
22(44.0)\end{array}$ & 0.04 \\
\hline HIV + ve on ARD $(n=7)$ & $\begin{array}{l}\text { Yes } \\
\text { No }\end{array}$ & $\begin{array}{l}1 \\
0\end{array}$ & $\begin{array}{l}0 \\
6\end{array}$ & 0.014 \\
\hline $\begin{array}{l}\text { No. of lifetime sex partner/s } \\
\qquad(n=56)\end{array}$ & $\begin{array}{l}\text { Single } \\
\text { Multiple }\end{array}$ & $\begin{array}{c}28(68.3) \\
0\end{array}$ & $\begin{array}{l}13(31.7) \\
15(100)\end{array}$ & $<0.001$ \\
\hline Age group $(n=58)$ & $\begin{array}{l}<40 \\
40+\end{array}$ & $\begin{array}{l}15(34.1) \\
14(100)\end{array}$ & $\begin{array}{c}29(65.9) \\
0\end{array}$ & $<0.001$ \\
\hline Age at first sex $(n=58)$ & $\begin{array}{l}<17 \\
17+\end{array}$ & $\begin{array}{l}20(71.4) \\
9(30.0)\end{array}$ & $\begin{array}{l}8(28.6) \\
21(70.0)\end{array}$ & 0.003 \\
\hline No of pregnancies $(n=45)$ & $\begin{array}{l}\leq 4 \\
5+\end{array}$ & $\begin{array}{l}13(38.2) \\
10(90.9)\end{array}$ & $\begin{aligned} 21 & (61.8) \\
1 & (9.1)\end{aligned}$ & 0.007 \\
\hline HPV type $(n=58)$ & $\begin{array}{l}\text { HPV } 16 \\
\text { HPV } 18 \\
\text { HPV } 33 \\
\text { Others }\end{array}$ & $\begin{array}{c}6(21.4 \%) \\
11(64.7 \%) \\
7(87.5 \%) \\
5(100 \%)\end{array}$ & $\begin{array}{c}22(78.6 \%) \\
6(35.3 \%) \\
1(12.5 \%) \\
0(0.0 \%)\end{array}$ & $<0.0001$ \\
\hline
\end{tabular}

Table 5: comparison of the mean viral load of various factors of HPV infection

\begin{tabular}{|c|c|c|c|}
\hline Factors & Mean Viral Load (IU/ml) & Confidence Interval & $p$ value \\
\hline \multicolumn{4}{|l|}{ HPV type } \\
\hline Type 16 & 4.90 & $-1.19506-0.18619$ & 0.036 \\
\hline Type 18 & 5.38 & & \\
\hline \multicolumn{4}{|l|}{ Cervical status } \\
\hline Normal LSIL & $\begin{array}{l}5.35 \\
5.66\end{array}$ & $-1.534571-0.93173$ & 0.6 .26 \\
\hline Age group & & $0.07160-1.29895$ & 0.029 \\
\hline$<40$ & 5.56 & & \\
\hline $40+$ & 4.84 & & \\
\hline Parity & & $0.25212-2.03242$ & 0.015 \\
\hline$\leq 4$ & 5.51 & & \\
\hline $5+$ & 4.35 & & \\
\hline Baseline viral load & 5.24 & $4.9428-5.5424$ & 0.000 \\
\hline Recall viral load & 4.60 & $2.2392-6.9508$ & 0.008 \\
\hline Viral load of LSIL at recall & 3.48 & $-9.27757-6.30424$ & 0.498 \\
\hline
\end{tabular}




\section{Discussion:}

The baseline study of the HPV status of the participants has been published (15). Persistence of cervical HPV infection was seen in $50 \%$ of the respondents after the six months follow up. Akaaboune et al., (17) reported persistence of $20.2 \%$ after 6 months and $22.4 \%$ after 12 months. Persistence of $59.6 \%$ (18) over a 24 month has equally been reported. We recognize that there is a possibility of further clearance of the HPV infection if the follow continued for a longer period. The outstanding thing in this follow up is a proportion $(24.1 \%)$ of those with persistent HPV infection that developed LSIL after 6 months of follow up. Some factors were peculiar with those who developed abnormal cervix after 6months. The factors include being infected with HPV 16, and HIV positivity without antiretroviral drugs. Higher persistence of HPV 16 has equally been reported in other studies $(18,19)$.

First cervical infection with HPV often occurs soon after first sexual intercourse (20). Some authors have suggested that early age at first sexual intercourse is an indicator for early exposure to HPV $(21,22)$. It has also been noted that high levels of circulating oestrogen during puberty may be a major influence in the metaplastic changes in the cervical transformation zone during that period (23). One will therefore expect that early onset of sexual intercourse may be associated with persistent HPV infection. This study, however, showed a lower persistence of HPV infection in the participants with early exposure to sexual intercourse.

There have been differing opinions on the use of hormonal contraceptives and cervical HPV persistence where some authors reported association $(13,24)$ while some others reported no association $(25,26)$. In this study, use of hormonal contraceptive was associated with HPV clearance instead of persistence though this should be interpreted with caution as the duration of hormonal contraceptive use and the type of contraceptives were not specified. Molano et al., (19) equally reported in their work that hormonal contraceptive aided HPV clearance. Persistence was more in participants with abnormal discharge and vaginal rash than those without though that of vaginal rash was not statistically significant. The presence of vaginal rash or abnormal discharge may mean co-infection with other STIs, hence the persistence.

Persistence was significantly higher in HIV patients who were not on ART and some of them had already developed LSIL at 6 months.
This persistence is in agreement with some other works $(27,28)$. Anti-retroviral drugs are known to reduce HIV viral load and so improves the immunity of the individual. Therefore, even when ART do not have direct effect on HPV, the improved immunity helps the individual to mount immunological defence against HPV leading to its clearance. A strong association has been found between HPV persistence and an increasing number of fullterm pregnancies in studies of pooled data analysis $(17,29)$ but the same was not obtained in this work as higher clearance of HPV infection was seen among the participants with up to 5 deliveries and above which was in line with the work of Kim et al., (30).

The risk of progression to pre-cancers is usually affected by the viral factors, host factors and the behavioural co-factors but the most important determinant of HPV infection to pre-cancers is the viral type (31). Cervical abnormalities persist longer and progress more quickly in women who have carcinogenic HPV infections than in women who have noncarcinogenic infections or no HPV (32). In agreement with above, HPV 16 in our study persisted more than other HPV types

The effect of HPV infection on development of cervical cancer has been said to be influenced by viral load, indicating that estimating load could improve the predictive value of HPV detection; however, the scope of quantification depends on the viral type being detected (33). In this study, HPV 16 viral load was lower than HPV 18, while load for participants with normal cervix was lower than for those with LSIL. The mean viral load at recall was equally lower than the mean viral load at baseline study, which could indicate that the immune systems of the participants are either attempting to clear the HPV infection or that some of the viruses are already integrated into the host's chromosomes (persistent HPV), thereby leading to low viral yield. This calls for further studies.

Kim et al., (30) and Deng et al., (34) equally detected low viral load in cervical cancer patient after treatment with radiotherapy and surgery respectively. In their research, they discovered that that low viral load was significantly associated with poor prognosis in cancer patients $(30,34)$. The above could not be verified in this work as we did not have any participant with HSIL or cancer after the follow up. Higher viral load in the younger age group seen in this study was equally witnessed by Ramanakumar et al., (35), which they attributed to the fact that these women were possibly exposed to HPV 
while they were immunologically naïve to HPV. The major limitations of this study are short time follow up and small sample size, and discrepancies encountered may be the result of this short term follow up and small sample size.

\section{Conclusion:}

Clearance of HPV infection after a 6month follow up among a cohort of women with normal cervical cytology was $50 \%$. Clearance of HPV 16 infection was lower than in other HPV types. Persistence of HPV infection is influenced mainly by infection with high-risk HPV types in combination with series of other risk factors peculiar to individuals. No one risk factor is enough for HPV persistence. A multiple of factors peculiar to an individual may have a very strong role to play in HPV progression

\section{References:}

1. Brown, D. R., Shew, M. I., Quadadri, B., et al. A Longitudinal study of genital Human Papillomavirus infection in a cohort of closely followed adolescent women. J Infect Dis. 2005; 191 (2): 182-192.

2. Clifford, G. M., Gallus, S., Herrero, R., et al. Worldwide distribution of Human Papillomavirus types in cytologically normal women in the international agency for research on cancer HPV prevalence surveys: a pooled analysis. Lancet. 2005; 366 (9490): 991-998

3. Bosch, F. X., and de Sanjose, S. Human Papillomavirus and cervical cancer-burden and assessment of casualty. J Natl Cancer Inst Monogr. 2003; 31: 3-13

4. Baseman, J. G., and Koutsky, L. A. The epidemiology of human Papillomavirus infections. J Clin Virol. 2005; 32 (Suppl 1): S16-S24

5. IARC Monographs. Biological agents: A review of human carcinogens. IARC Monogr Eval Carcinog Risk Hum. 2012; 100B: 1-499

6. de Jong, A., van Poelgeest, M. I., van der Hulst., et al. Human papillomavirus type 16-positive cervical cancer is associated with impaired CD4+ T-cell immunity against early antigens E2 and E6. Cancer Res. 2004; 64: 5449-5455

7. Stanley, M. HPV - immune response to infection and vaccination. Infect Agents Cancer. 2010; 5: 19

8. Bosch, F. X., Lorincz, A., Munoz, N., Meijer, C. J., and Shah, K. V. The causal relation between human papillomavirus and cervical cancer. J Clin Pathol. 2002; 55: 244-265.

9. Travassos, A. G., Netto, E., Xavier-Souza, E., et al. Predictors of HPV incidence and clearance in a cohort of Brazilian HIV-infected women. PLoS One. 2017; 12 (10): e0185423.ht

10. Soto-De León, S. C., Río-Ospina, L. D., et al. Persistence, clearance and reinfection regarding six high risk human papillomavirus types in Colombian women: a follow-up study. BMC Infect Dis. 2014; 14: 395

11. Trevisan, A, Schlecht N. F, Ramanakumar, A. V., et al. Human papillomavirus type 16 viral load measurement as a predictor of infection clearance. J Gen Virol. 2013; 94 (Pt 8): 18501857.
12. Depuydt, C. E., Criel A. M., Benoy I. H., et al. Changes in type-specific human papillomavirus load predict progression to cervical cancer. J Cell Mol Med. 2012; 16: 3096-3104. 10.1111/j.15824934.2012.01631.x

13. Marks, M., Gravitt, P. E., Utaipat, U., et al. Kinetics of DNA load predict HPV 16 viral clearance. J Clin Virol. $2011 ; 51: 44-49$.

14. Xi, F. L., Hughes, J. P., Castle, P. E., et al. Viral Load in the Natural History of Human Papillomavirus Type 16 Infection: A Nested Casecontrol Study. J Infect Dis. 2011; 203 (10): 14251433. doi: $10.1093 /$ infdis/jir049

15. Ezebialu, C. U., Ezebialu, I. U., Ezeifeka, G. O., et al. Prevalence of Cervical Human Papillomavirus Infection in Awka, Nigeria. J Biosci Med. 2020; 8: 37-47. https://doi.org/10.4236/jbm.2020.83005

16. Okpere, E. Clinical gynaecology Revised edition. Mindex publishing company limited, Benin. 2007; 160-173

17. Akaaboune, M., Kenfack, B., Viviano, M., et al. Clearance and persistence of the human papillomavirus infection among Cameroonian women. Women's Health. 2018; 14: 1-9 DOI: $10.1177 / 1745506518805642$

18. Miranda, P. M, Silva, N. N. T., Pitol, B. C. V., et al. Persistence or Clearance of Human Papillomavirus Infections in Women in Ouro Preto, Brazil. BioMed Res Int. 2013; 578276, 6 pages http://dx.doi.org/10.1155/2013/578276

19. Molano, M., Van den Brule, A., Plummer, M., et al. Determinants of clearance of Human Papillomavirus infection in Columbian women with normal cytology: a population based, 5 year follow up study. Am J Epidemiol. 2003; 158: 486-494

20. Plummer, M., Peto, J., Franceschi, S., et al. Time since first sexual intercourse and the risk of cervical cancer. Int J Cancer. 2012; 130 (11): 2638-2644

21. Heywood, W., Patrick, K., Smith, A. M. A., et al. Associations between early first sexual intercourse and later sexual and reproductive outcomes: A systematic review of population-based data. Archives of Sexual Behaviour; 2015; 44 (3): 531569

22. Lara, L. S. A., and Abdo, C. H. N. Age at initial sexual intercourse and health of adolescent girls. J Paed Adolescent Gynaecol. 2015; 29 (5):1-7

23. Motoyama, S., Ladines-Llave, C. A., Villanueva, S. L., and Maruo, T. Minireview of the role of Human Papillomavirus in the molecular biology of cervical carcinogenesis. Kobe J Med Sci. 2004; 50 (1): 919

24. Volpato, L. K., Siqueira, I. R., Nunes, R. D., and Piovezan, A. P. Association between Hormonal Contraception and Injuries Induced by Human Papillomavirus in the Uterine Cervix. Rev Bras Ginecol Obstet. 2018; 40: 196-202.

25. Maucort-Boulch, D., Plummer, M., Castle, P. E., et al. Predictors of human papillomavirus persistence among women with equivocal or mildly abnormal cytology. Int J Cancer. 2010; 126: 684-691

26. Munoz, N., Hernandez-Suarez, G., Mendez, F., et al. Persistence of HPV infection and risk of highgrade cervical intraepithelial neoplasia in a cohort of Colombian women. Br J Cancer. 2009; 100 (7): 1184-1190.

27. Ezechi, O. C., Pettersson, K. O., Okolo, C. A., et al. The Association between HIV Infection, Antiretroviral Therapy and Cervical Squamous Intraepithelial Lesions in South Western Nigerian Women. PLoS One 2014; 9 (5): e97150. doi:10.1371/journal.pone.0097150

28. McKenzie, K. P., Rogers, R. K, Njoroge, J. W., et al. Cervical squamous intraepithelial lesions among 
HIV-positive women on antiretroviral therapy in Kenya. Current HIV Res. 2011; 9 (3): 180-185

29. Jensen, K. E., Schmiedel, S., Norrild, B., et al. Parity as a cofactor for high-grade cervical disease among women with persistent human papillomavirus infection: a 13 -year follow-up. $\mathrm{Br} \mathrm{J}$ Cancer. 2013; 108: 234-239. doi: 10.1038/bjc. 2012.513

30. Kim, J. W., Song, S. H., Jin, C. H., et al. Factors Affecting the Clearance of High-risk Human Papillomavirus Infection and the Progression of Cervical Intraepithelial Neoplasia. J Int Med Res. 2012; 40: 486 - 496

31. Nobbenhuis, M. A. E, Walboomers, J. M. M, Helmerhorst, T. J. M., et al. Relation of human papillomavirus status to cervical lesions and consequences for cervical cancer screening: A prospective study. Lancet. 1999; 354: 20-25
32. Schlecht, N. F., Platt, R. W., Duarte-Franco, E., et al. Human papillomavirus infection and time to progression and regression of cervical intraepithelial neoplasia. J Natl Cancer Instit. 2003; 95: 1336-1343

33. Río-Ospina, L. D., Soto-De León, C. S., Camargo, M., et al. The DNA load of six high-risk human papillomavirus types and its association with cervical lesions. BMC Cancer. 2015; 15: 100-111

34. Deng, T., Feng, Y., Zheng, J., et al. Low initial human papillomavirus viral load may indicate worse prognosis in patients with cervical carcinoma treated with surgery. J Gynaecol Oncol. 2015; 26 (2): 111-117

35. Ramanakumar, A. V., Goncalves, O., Richardson, $\mathrm{H}$., et al. DNA loads and HPV-16 integration in persistent and transient infections in young women. BMC Infect Dis. 2010; 10: 326-338 